\title{
Do Mixed Fire Regimes Shape Plant Flammability and Post-Fire Recovery Strategies?
}

\author{
Helen M. Poulos ${ }^{1, *} \mathbb{C}$, Andrew M. Barton ${ }^{2}$, Jasper A. Slingsby ${ }^{3,4} \mathbb{D}$ and \\ David M.J.S. Bowman 5 (D) \\ College of the Environment, Wesleyan University, Middletown, CT 06459, USA \\ Department of Biology, University of Maine at Farmington, Farmington, ME 04938, USA; barton@maine.edu \\ Fynbos Node, South African Environmental Observation Network, Claremont 7735, South Africa; \\ jasper@saeon.ac.za \\ 4 Centre for Statistics in Ecology, Environment and Conservation, Department of Biological Sciences, \\ University of Cape Town, Rondebosch 7701, South Africa \\ 5 School of Natural Sciences, University of Tasmania, Private Bag 55, Hobart, TAS 7001, Australia; \\ david.bowman@utas.edu.au \\ * Correspondence: hpoulos@wesleyan.edu; Tel.: +1-860-685-4205
}

Received: 20 September 2018; Accepted: 16 October 2018; Published: 22 October 2018

\begin{abstract}
The development of frameworks for better-understanding ecological syndromes and putative evolutionary strategies of plant adaptation to fire has recently received a flurry of attention, including a new model hypothesizing that plants have diverged into three different plant flammability strategies due to natural selection. We provide three case studies of pyromes/taxa (Pinus, the Proteaceae of the Cape Floristic Region, and Eucalyptus) that, contrary to model assumptions, reveal that plant species often exhibit traits of more than one of these flammability and post-fire recovery strategies. We propose that such multiple-strategy adaptations have been favoured as bet-hedging strategies in response to selective pressure from mixed-fire regimes experienced by these species over evolutionary time.
\end{abstract}

Keywords: fire-adapted traits; fire severity; fire risk; fire-prone ecosystems; fire regimes; mixed-severity fire regimes; plant flammability; plant flammability strategies

\section{Introduction}

Fire is a global ecological disturbance agent that exerts strong evolutionary pressure on plants. How fire shapes plant evolution is currently a topic of extensive debate, given the recent spate of large, destructive wildfires worldwide [1-3]. Key aspects of fire regimes, including frequency, season, type, severity, and spatial pattern, exert selective pressure on plants, and promote the development of a range of fire-adapted traits, including thick bark for insulating trees from heat damage, post-fire resprouting from both above- and below-ground tissues, serotiny, self-pruning of lower canopy branches as a means of avoiding crown fire, and heat- or smoke-induced seed germination. Many adaptations for both gymnosperms and angiosperms to resist and recover from fire appear to have arisen in the Cretaceous or before in response to increases in wildfire activity [4-7], and recent evidence suggests that such traits have evolved repeatedly and independently around the globe in flammable landscapes [8-13]. More controversially, some authors have also posited that plants have increased their flammability to gain competitive advantages against less fire-tolerant species [14-16].

A powerful approach to understanding variation among species subject to key selective forces such as fire is to identify differing suites of correlated traits (ecological syndromes), and, if warranted, to test the hypothesis that these syndromes represent evolutionary strategies shaped by natural 
selection and functional trade-offs. Rowe [17] was the first to group fire-adaptive traits into ecological syndromes and propose associated evolutionary strategies, including: fire invaders (pioneers that establish immediately after fire), evaders (plants with heat-induced seed dispersal or germination), avoiders (fire refugial taxa), resisters (thick-barked plants), and endurers (resprouters). Other studies have altered the original Rowe conceptual model to explore the evolution of strategies of plants in fire-prone ecosystems (e.g., [10,18]). More recently, Pausas, et al. [19] developed a more complex, multi-dimensional approach to fire-adaptative traits, based on whole-plant flammability as a key way to identify ecological syndromes. They ordered plant species along three ecological flammability axes and hypothesized that plants have diverged into three corresponding evolutionary strategies: "non-flammable" plants that do not burn in fires, "fast-flammable" plants that ignite quickly but experience minimal heat residence time, and "hot-flammable" plants with adaptations for promoting and exploiting hot fires with high residence times. They posited that natural selection has driven species towards the ends of these axes to form clearly defined strategies that represent alternative, largely mutually exclusive mechanisms for plants to succeed in fire-prone environments.

This recent framework provides a novel emphasis on flammability concepts and provides a means for building an increased understanding of the nature of plant adaptations to fire and the ways in which organisms interact with their environments. However, there is also increasing recognition that spatio-temporal variation is an inherent feature of landscape fires and that plant species express high levels of diversity in fire-adaptations (e.g., [20]), which is an underemphasized factor that in the Pausas, Keeley, and Schwilk [19] framework. Adaptations for persisting in fire-prone environments have evolved in the context of substantial variation in fire regimes over long time-scales [21,22], especially since fire characteristics can vary dramatically across a single species' distribution, from fire-to-fire at the same site, and even within the area of a single fire event [23-25]. Other papers (e.g., Prior et al., 2018) have examined the ecological flammability aspects of the Pausas, Keeley, and Schwilk [19] model. The purpose of this paper is to broaden the utility of the Pausas, Keeley, and Schwilk [19] framework and to contribute to the development of multidimensional flammability and post-fire response models that incorporate the following concepts: (1) plant species often exhibit traits of more than one flammability strategy which can confer survival and reproductive advantages in response to fire; (2) many plant species fall at intermediate, not extreme, positions along the plant flammability gradient; and (3) mixed-fire regimes may be an important pressure for the evolution of fire-adapted traits leading to species mapping onto multiple strategies.

\section{Species Exhibiting Multiple Flammability Strategies}

A central tenet of frameworks of fire-adaptation strategies, such as that of Pausas, Keeley, and Schwilk [19], is that natural selection has favoured the evolution of sets of correlated, reinforcing, and largely mutually exclusive traits that confer fitness advantages in fire-prone environments which are expressed as clearly identifiable evolutionary strategies. For instance, plants living in pyromes characterized by low intensity fires survive because they have thick insulative bark or self-prune lower branches to avoid crown fire, etc. Conversely, such strategies are absent in species that evolved under hotter fire regimes that favour plant flammability strategies such as the activation of dormant buds from tissue injury or fire-stimulated seed germination. Pausas, Keeley, and Schwilk [19] also argue that "While many plants fall at intermediate levels of these axes (i.e., the null model for flammability), plants in fire-prone ecosystems benefit from being at the extremes, forming the three flammability strategies..." In other words, in fire-prone areas, species should tend to exhibit only one flammability strategy composed of a set of correlated traits falling at the extreme of one of the three strategies rather than at intermediate positions. We address these expected outcomes with case studies from three different pyromes/taxa. Our analysis reveals that species exhibit tremendous diversity in traits promoting the tolerance of and recovery from fire that often do not map neatly onto clearly defined evolutionary end points. 


\section{Case Studies}

\subsection{Pinus}

The negative correlation between serotiny and self-pruning in trees has been repeatedly used as evidence for the evolution of flammable plants in high-severity wildfire systems. While the evolution of serotiny as an adaptation to high-intensity crown fire is well-established $[10,13,26]$, this assertion fails to acknowledge that some members of Pinus exhibit serotiny but also thick bark and self-pruning. Others have one or more of these traits, and can also sprout after fire-induced tissue damage. For example, P. leiophylla, from the southwestern United States and northern Mexico, exhibits semi-serotinous cones, thick bark, and moderate post-fire basal and epicormic resprouting [27-31]. The same is true for $P$. pungens, which has serotinous cones, intermediate bark thickness, and the capacity to resprout in response to fire [26,32-35]. In fact, rather than occurring exclusively at one of the three flammability extremes postulated by Pausas, Keeley, and Schwilk [19], many species within Pinus exhibit traits that map onto intermediate positions along flammability axes with more than one strategy (Figure 1, Table 1A).

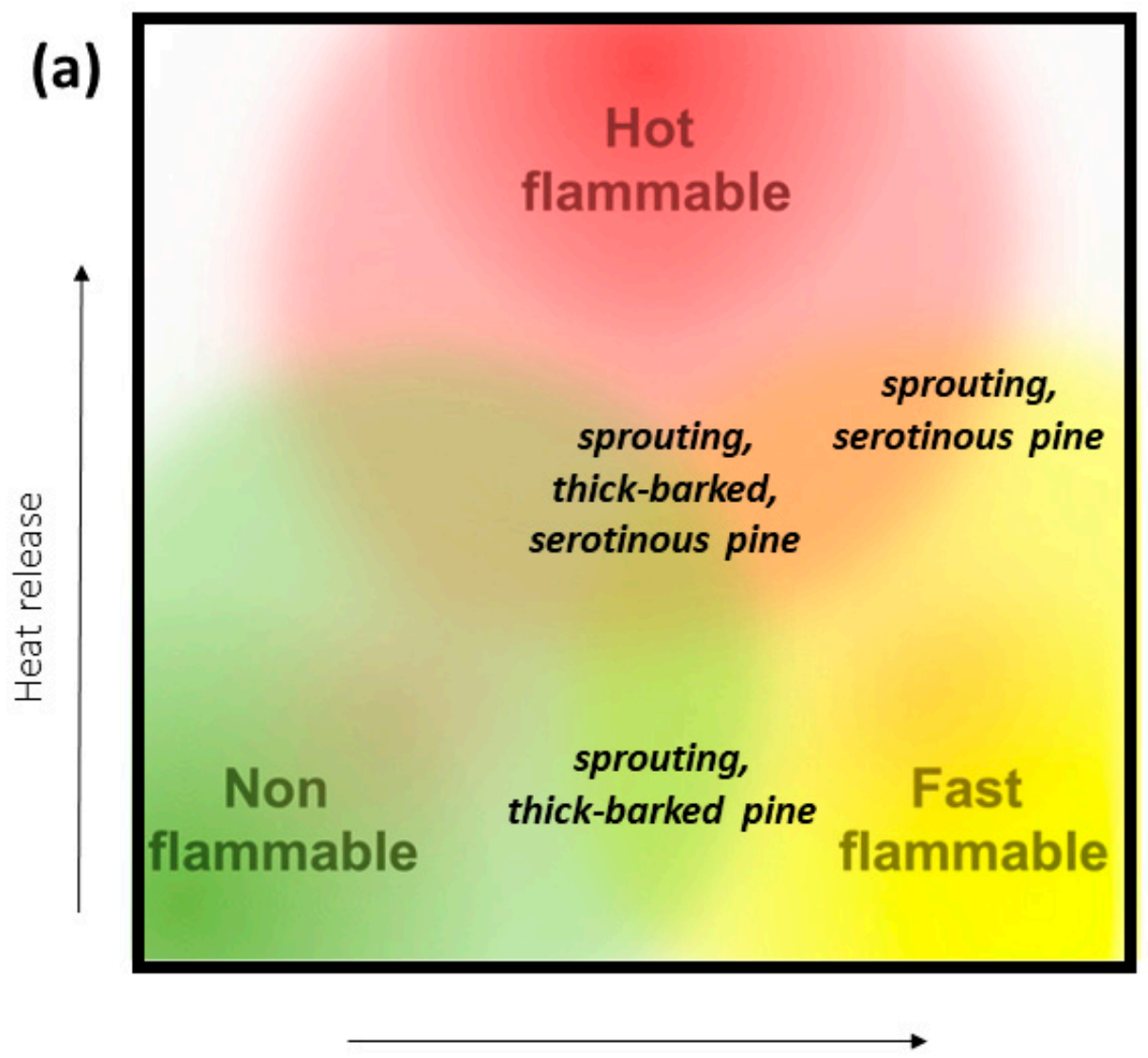

Flame spread rate

Figure 1. Cont. 


\section{nMDS}

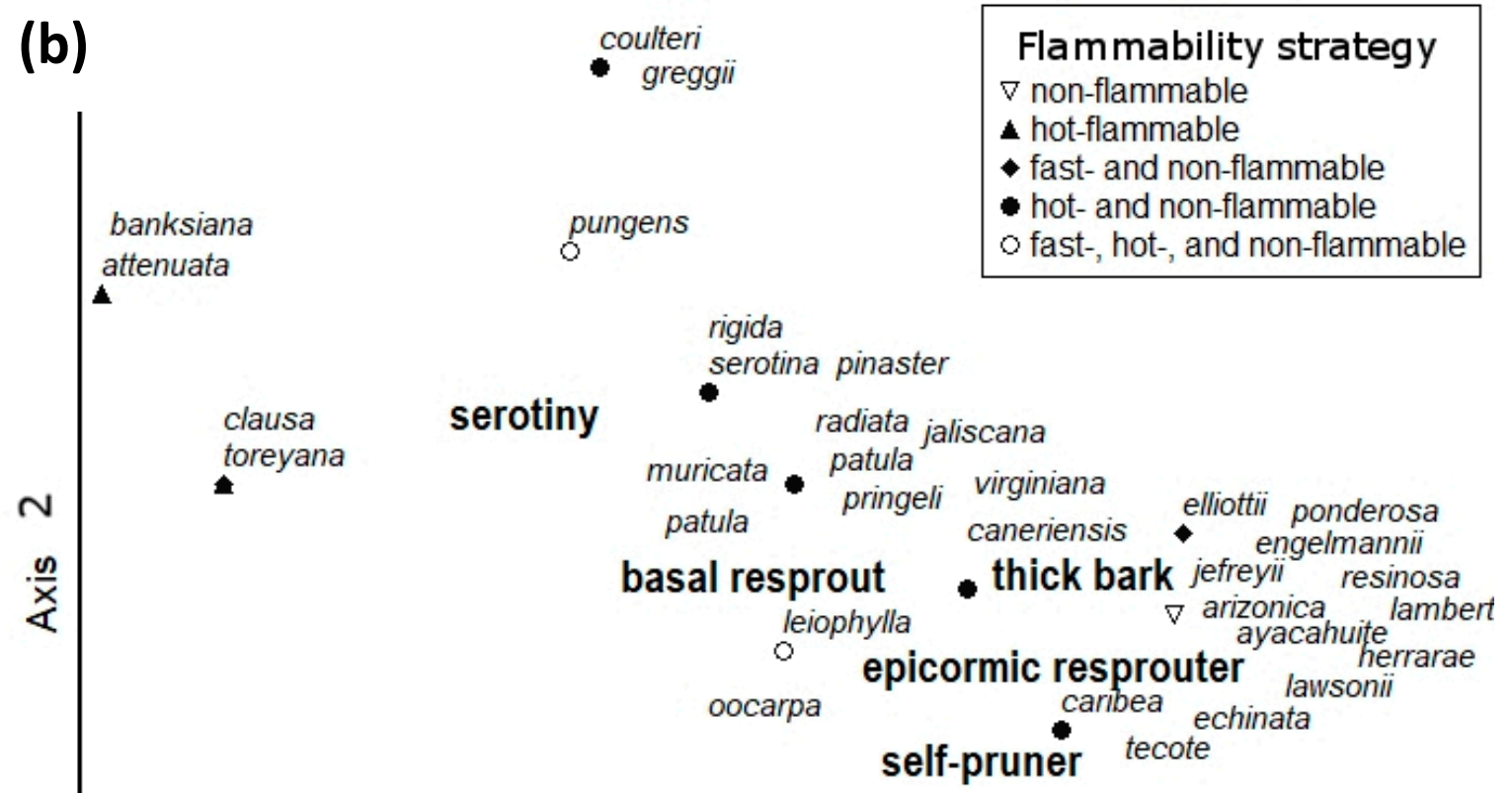

halapensis

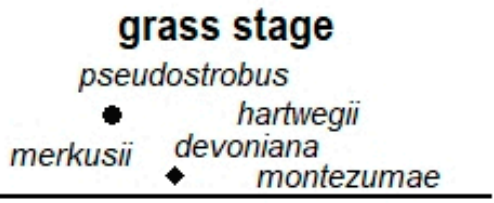

Axis 1

Figure 1. (a) Revised version of the conceptual flammability model of Pausas, Keeley, and Schwilk [20] depicting where pines with multiple fire-adapted traits fall on the three axes of variation in plant flammability, and (b) non-metric multidimensional scaling (nMDS) of fire-adapted traits for the members of the Pinus genus with (1) multiple fire-adapted traits listed in Table 1A and (2) traits for taxa with only single flammability strategy taken from Appendix 21.1 in Keeley and Zedler [26]. Species with multiple flammability strategies in this ordination were identified through an exhaustive review of the literature on Pinus. Species are plotted in trait space and are displayed according to flammability strategy via the nMDS of species by traits (i.e., presence/absence) using relative Euclidean distances and PC-Ord software [36]. The final stress for the ordination was 0.0749 . While some members of the Pinaceae fall at the extremes, the ordination diagram clearly shows that many species fall at the center of the nMDS and possess multiple fire-adapted traits. 


\subsection{Proteaceae of the Cape Floristic Region, South Africa}

The Cape Floristic Region (CFR) is a fire-dominated global biodiversity hotspot [37]. Plant communities of the CFR commonly have an overstory of shrubs and small tree species, with many from the Proteaceae family. With roughly 300 species in 14 genera, the Proteaceae of the CFR span almost the full range of woody plant life-history traits [38], and variation in fire survival mode in the CFR is commonly touted as one of the mechanisms facilitating the coexistence and maintenance of high diversity across the region [39]. The CFR Proteaceae typically burn at high fire severity and are adapted to such a fire regime due to aerial or soil seed banking [40], although most genera in this family also contain intermediates along the plant flammability gradient (Table 1B). For example, of the 81 Leucadendron species studied by Tonnabel, et al. [41], they identify 10 that exhibit both serotiny or soil-stored seed banks and post-fire basal resprouting, which is an important example of how multiple flammability strategies can operate within one species. This number is higher in the Cape species of Protea, with 19 of 79 having fire-adapted traits that place them in multiple flammability strategy categories [38]. Other species such as Leucospermum conocarpodendron, Mimetes fimbriifolius and Leucadendron argenteum combine high-severity wildfire traits like serotiny or soil seed banking with lower fire-severity strategies like thick bark that reduces adult fire-mortality [38]. Lastly, Protea nitida is the only species in the Cape Proteaceae that combines thick bark and epicormic resprouting, but has no seed bank. However, this strategy is far more common in the summer-rainfall Protea species, which are subject to less severe, grass-driven surface fires [38]. 
Table 1. Flammability strategies of the (A) Pinaceae and (B) Proteaceae from the Cape Floristic Region of South Africa for species with multiple flammability strategies.

\begin{tabular}{|c|c|c|c|c|c|c|c|c|c|}
\hline Taxon & Grass Stage & Basal Resprout & Epicormic Resprout & Seed Banker & Serotiny & Thick Bark & Self-Pruning & Flammability Strategy & Source \\
\hline \multicolumn{10}{|c|}{ (A) Pinaceae } \\
\hline Pinus canariensis & + & + & + & - & - & + & - & fast and non-flammable & {$[26,42,43]$} \\
\hline P. caribaea var. hondurensis & - & + & + & - & - & + & + & fast and non-flammable & {$[6,44]$} \\
\hline P. devoniana & \pm & - & - & - & - & + & + & fast and non-flammable & {$[26,45]$} \\
\hline P. echinata & - & + & + & - & - & + & + & fast and non-flammable & [46] \\
\hline P. elliottii var. densa & - & + & - & - & - & + & + & fast and non-flammable & {$[13,47,48]$} \\
\hline P. hartwegii & \pm & + & + & - & - & + & + & fast, hot, and non-flammable & {$[44,46]$} \\
\hline P. halapensis & \pm & - & - & - & \pm & + & + & fast and hot-flammable & [49-51] \\
\hline P. leiophylla & - & + & + & - & \pm & + & + & fast, hot, and non-flammable & {$[27-30]$} \\
\hline P. merkusii & \pm & - & - & - & - & + & + & fast and non-flammable & {$[26,52]$} \\
\hline P. montezumae & \pm & - & - & - & - & + & + & fast and non-flammable & {$[26,53]$} \\
\hline P. оocarpa & - & + & + & - & \pm & + & + & fast, hot and non-flammable & {$[26,54]$} \\
\hline P. patula & - & - & - & - & \pm & + & + & fast and hot-flammable & {$[26,44]$} \\
\hline P. pinaster & - & - & - & - & \pm & + & + & fast and non-flammable & {$[49,55,56]$} \\
\hline P. pseudostrobus & \pm & + & + & - & - & + & + & fast, hot, and non-flammable & {$[6,44,46]$} \\
\hline P. pungens & - & + & - & - & \pm & + & - & fast, hot, and non-flammable & {$[26,32-35]$} \\
\hline P. rigida & - & + & + & - & \pm & + & - & fast and non-flammable & {$[26,57]$} \\
\hline P. serotina & - & + & + & - & \pm & + & - & fast, hot, and non-flammable & {$[26,58-60]$} \\
\hline P. tecote & - & + & + & - & - & + & + & fast, hot, and non-flammable & {$[6,44,46]$} \\
\hline P. torreyana & - & - & - & - & + & + & - & fast and non-flammable & [26] \\
\hline P. virginiana & - & + & + & - & - & + & - & fast and non-flammable & {$[6,26]$} \\
\hline \multicolumn{10}{|c|}{ (B) Cape Floristic Region Proteaceae } \\
\hline Aulax pallasia & - & + & - & - & + & - & - & fast and hot flammable & [38] \\
\hline Leucospermum cuneiforme & - & + & - & + & - & - & - & fast and hot flammable & [38] \\
\hline Leucospermum conocarpodendron & - & - & - & + & - & + & - & hot and non-flammable & [38] \\
\hline Mimetes fimbriifolious & - & - & - & + & - & + & - & hot and non-flammable & [38] \\
\hline Mimetes cucculatus & - & + & - & + & - & - & - & fast and hot flammable & [38] \\
\hline Leucadendron salignum & - & + & - & - & + & - & - & fast and hot flammable & [38] \\
\hline Leucadendron argenteum & - & - & - & - & + & + & - & hot and non-flammable & [38] \\
\hline Protea cynaroides & - & + & - & - & + & - & - & fast and hot flammable & [38] \\
\hline Protea nitida & - & - & + & - & - & + & - & fast and non-flammable & [38] \\
\hline
\end{tabular}




\subsection{Eucalyptus}

Eucalyptus is a notoriously flammable plant genus [61], and nearly all species have multiple characteristics that help them resist mortality and recover from fire, including lignotubers [62,63], epicormic bud resprouting [64], serotinous fruits [65-67], and clonal root suckering [66,68]. Nicolle [67] classified over 700 taxa in the eucalypt clade as being an (a) obligate seeder, (b) lignotuber resprouter, (c) stem resprouter, and (d) combination resprouter (Figure 2). Rather than showing a clear association between climate and fire regimes [69], the biogeographical pattern of these regeneration strategies is complex, as outlined below. Some eucalypt species in infrequently-burnt environments have down-regulated vegetative recovery mechanisms, and instead rely on serotinous, aerial seed banks. The best-known examples (such as E. regnans, the world's tallest angiosperm) occur in highly productive environments, with high soil fertility and moisture availability [70]. In these forests, the risk of crown fire is highest in the immature stage [71,72], which is contrary to the notion that landscape flammability is closely correlated with serotiny. Furthermore, these species can partially resist low-severity ground fires, leading to multi-cohort stands (i.e., not all fires are uniformly high-severity and stand-replacing [71,73]). This is even more noticeable in a little known and diverse concentration of obligate-seeder eucalypts found in low-productivity semi-arid woodlands in south-western Australia (Figure 2a). Mature woodlands occur with low loads of discontinuous litter fuels and, are therefore "fire-resistant," and appear to be able to regenerate in the absence of fire. However, extreme fire weather or high fuel loads can lead to stand-replacing fires [74]. Why these woodlands are dominated by obligate seeders remains unclear, given that environmentally comparable semi-arid woodlands in south-eastern Australia are dominated by strong resprouters (Figure 2).

Eucalypt species that have a wide environmental range, and hence exposure to various fire regimes, show marked variation in the intensity of lignotuberous resprouting, bark thickness, and height of fibrous bark on trunks (e.g., [75-77]). This is well-illustrated by the regeneration strategies of Eucalyptus delegatensis, a tall forest tree that is closely related to E. regnans. The mainland Australian subspecies has a rough fibrous stocking that extends about one third up its trunk, enabling it to withstand low-severity surface fires that occur in open, grassy understoreys in old-growth, multi-aged, and continuously-regenerating forests [78]. Yet, under high-severity fire regimes, stands of this species can be killed, leaving the sole regeneration strategy as a canopy seedbank that disperses with fire damage. Following stand-replacing fires, the immature cohort is vulnerable to fire kill due to both high stem density and high shrub cover [79], with multiple fires leading to local extinction [80]. Nonetheless, frequent fires can select for precocious flowering genotypes [81]. By contrast, the Tasmanian form of E. delegatensis has fibrous bark extending into the lower branches of the crown, with a well-developed epicormic response and lignotuberous saplings [82]. Unlike the mainland Australian form, which is restricted to moist fertile sites, the Tasmanian subspecies spans a wide environmental gradient, from infrequently burnt temperate rainforests to forests with a high frequency of low-severity surface fires [82,83]. The mainland Australian and Tasmanian subspecies of E. delegatensis thus provide a prime example of a fire-adapted tree species with a wide environmental amplitude, spanning multiple fire regimes ranging from frequent, mid-severity surface-fires to infrequent low-severity fires or stand-replacing fires, thereby spanning the entire gradient of plant flammability strategies. Why and when the divergence of the two subspecies post-fire responses occurred remains unclear and warrants investigation. 

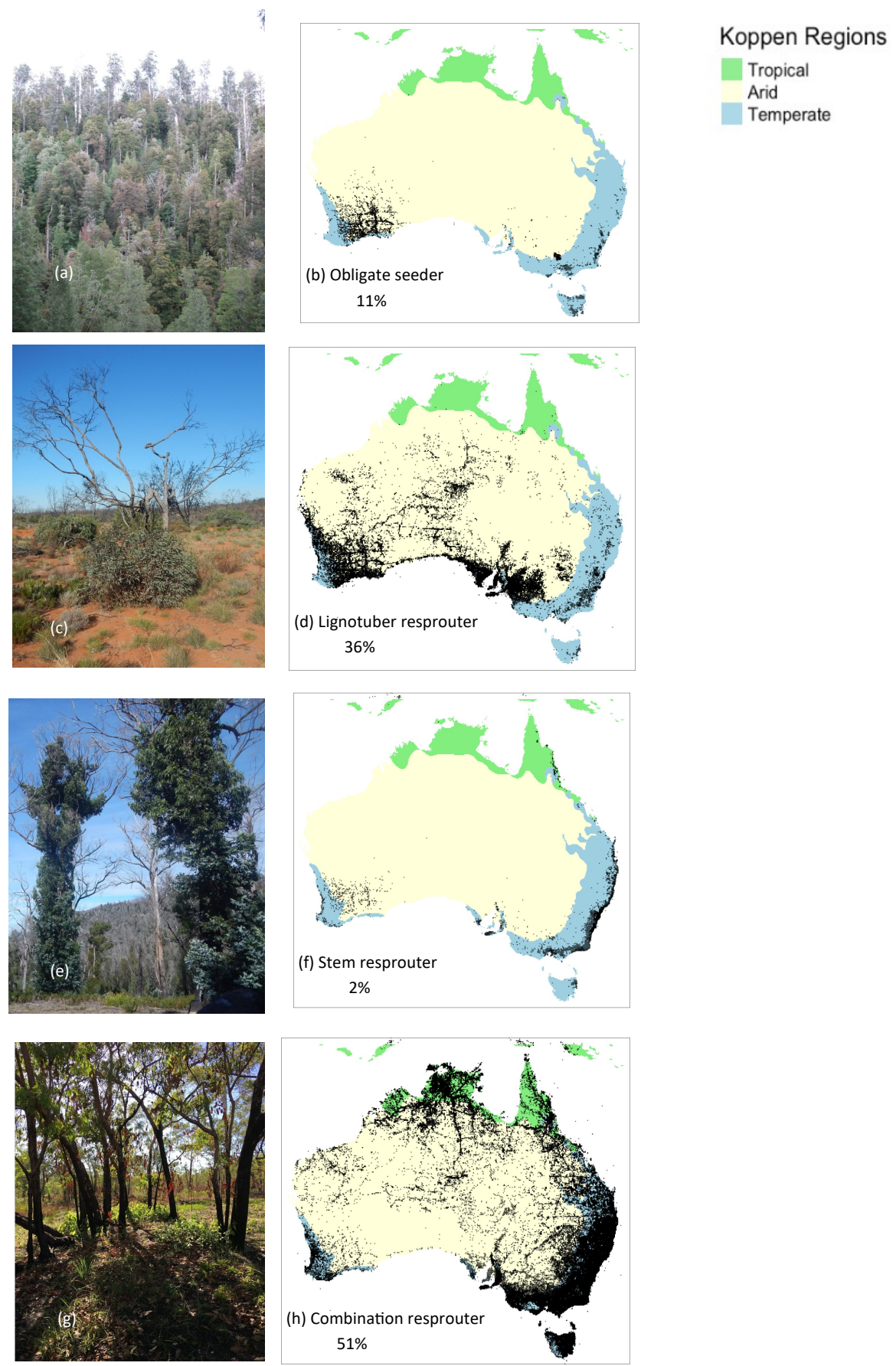

Figure 2. Four post-fire regeneration strategies according the classification of Nicolle (2006) (a-h): (a) and (b) obligate seeder, (c,d) lignotuber resprouter, (f) stem resprouter, and (e-h) combination resprouter for 723 taxa (species, subspecies and hybrids) within the eucalypt clade. The continental distributions of the four regeneration strategies and the tropical (green), arid (yellow) and temperate (blue) Koppen regions are shown in the maps. Photographs of each of these four regeneration strategies are also shown for (a) the obligate seeder E. regnans forest above a Nothofagus rainforest in western Tasmania (=non-flammable strategy of Pausas, Keeley, and Schwilk [19]); (c) lignotuberous 'mallee' E. socialis in semi-arid southeastern Australia (=hot flammable strategy [19]); (e) stem resprouting in the combination resprouter E. globulus forests in dry temperate Tasmania (=hot flammable strategy [19]); and (h) combination resprouter E. tetrodonta in tropical savanna (=fast flammable strategy [19]). The distribution data are sourced from the Atlas of Living Australia (ALA, http:/ / www.ala.org.au. Accessed 8 December 2017). Note some hybrids listed by Nicolle [67] were not available in ALA. 


\section{Mixed-Fire Regimes}

Variation in topography, climate, and fire weather engender heterogeneity in wildfires across geographic space, as well as over historical and paleo time-scales. This variability in fire frequency, intensity, and other behavioural aspects results in mosaics of intermixed patches of plant survival, fuel loads, and flammabilities across landscapes [20,22,84-92]. Spatiotemporal variation in live and dead vegetation quantities in relation to the fire regime generates vegetation mosaics that can amplify abiotic influences of the landscape on fire behaviour. As a result, over evolutionary time, many plant species in fire-prone ecosystems experience fires that vary in their characteristics across both time and space. These mixed-fire regimes (fires that burn across a range of fire behaviours, thereby killing different amounts of vegetation [93]) impose variation in selection pressures, which may favour bet-hedging (sensu [94]) through the evolution of multiple resistance and recovery mechanisms for persisting in a variable but fire-prone environment, as demonstrated in our case studies. In other words, fire regimes (and the characteristics of any given fire) are the complex product of climate, topography, and all plant species constituting the community. They are only partially influenced by the flammability of a single species. Such shifting patchworks of fire behaviour represent barriers for the evolution of traits that expressly drive traits towards the extremes of the flammability gradient, as argued in Pausas, Keeley, and Schwilk [19]. Instead, mixed-fire regimes may favour the evolution of multiple fire adaptations in species that fall within more than one of the evolutionary strategies hypothesized by Pausas, Keeley, and Schwilk [19]. A similar scenario has been demonstrated for variation in germination strategies in arid land plants driven in part by climate variation [95].

Contrasting fire regimes across the range of a single, but widely-distributed plant species has led to ecotypic differentiation in strategies for persistence in fire-prone environments [96], as described in our eucalyptus case study. In other words, some apparent cases of multiple fire-adapted traits in a species might be attributable to a collective set of characters summed across populations, where each population is adapted to its current local environment and historical variation in fire regimes and environmental conditions over time. For example, substantial variation in serotiny among populations has been well documented in P. banksiana, P. contorta, and P. rigida in response to different fire histories [97-100]. Such ecotypic variation could represent multiple instances of evolution to strategies described in Pausas, Keeley, and Schwilk [19] rather than bet-hedging strategies in a species. Yet, from our observations as a whole, we propose that, within most species, fire-adapted traits falling into multiple evolutionary strategies reflect species-level characteristics that are promoted by repeated exposure to mixed-severity fire regimes over evolutionary time. Examination of ecotypic differentiation in fire-adaptations across fire regime gradients might provide a powerful way to test some of the contrasting ideas presented this paper, as well as those in Pausas, Keeley, and Schwilk [19].

As described by Pausas, Keeley, and Schwilk [19], some species exhibit fire-associated adaptations falling within multiple flammability strategies across life stages for species at the same location. They cite the striking differences between the "fast-flammable," "grass-stage" seedlings versus the "non-flammable," mature stage of P. palustris as evidence of this phenomenon. Such variation has likely emerged because these life stages, due to their contrasting stature, experience the same fire in different ways: seedlings as a fast-moving fire that briefly engulfs them, and the mature tree as a surface fire that passes below with little immediate impact. Thus, selection associated with variation in fire characteristics can act at multiple levels within species: vertically among life stages (leading to contrasting fire-adaptations), geographically across populations (leading to ecotypes), and across historical and paleo time-scales and space (leading to bet-hedging adaptations falling into multiple strategies at the same life stage within populations).

\section{Conclusions}

Frameworks of evolutionary strategies of fire-adapted traits, such as those of Rowe [17] and Pausas, Keeley, and Schwilk [19], are instrumental in theorizing about the evolution of plants to recurrent landscape fires. Although a modicum of species can deviate from such generalizations, 
multiple anomalies or inconsistencies in these ideas might suggest that the fire-dominated world is indeed more complicated. We have provided such evidence here, in contrast to the assumptions of the Pausas, Keeley, and Schwilk [19] model, that many species within at least three pyromes/taxa exhibit apparent fire-adaptations falling into multiple strategies, and, further, that such diverse sets of traits may have evolved in response to mixed-fire regimes. We agree with Pausas et al (2017) that differences in flammability among plants, no matter how they evolved, are a crucial aspect of our knowledge of plant strategies for persisting in fire-prone environments. Understanding the evolution of flammability and the connections between flammability and other adaptations remain exciting frontiers in the field of fire ecology.

Author Contributions: H.M.P. and A.M.B. contributed equally to the conceptual development and writing with D.M.J.S.B., and J.A.S. wrote the case studies on Eucalyptus and the Cape Proteaceae, respectively. All authors contributed to both the theoretical and empirical perspectives of the manuscript.

Funding: This research received no external funding.

Acknowledgments: The authors wish to thank Steven Davis for helpful comments on the manuscript. We also thank Tierney O'Sullivan and Grant Williamson for helping with Figure 2.

Conflicts of Interest: The authors declare no conflict of interest.

\section{References}

1. Jolly, W.M.; Cochrane, M.A.; Freeborn, P.H.; Holden, Z.A.; Brown, T.J.; Williamson, G.J.; Bowman, D.M.J. Climate-induced variations in global wildfire danger from 1979 to 2013 . Nat. Commun. 2015, 6, 7537. [CrossRef] [PubMed]

2. Westerling, A.L. Increasing western us forest wildfire activity: Sensitivity to changes in the timing of spring. Philos. Trans. R. Soc. B 2016, 371, 20150178. [CrossRef] [PubMed]

3. Bowman, D.M.J.S.; Williamson, G.J.; Abatzoglou, J.T.; Kolden, C.A.; Cochrane, M.A.; Smith, A.M.S. Human exposure and sensitivity to globally extreme wildfire events. Nat. Ecol. Evol. 2017, 1, 0058. [CrossRef] [PubMed]

4. Bond, W.J.; Midgley, J.J. Fire and the angiosperm revolutions. Int. J. Plant Sci. 2012, 173, 569-583. [CrossRef]

5. Bond, W.J.; Midgley, J.J. The evolutionary ecology of sprouting in woody plants. Int. J. Plant Sci. 2003, 164, S103-S114. [CrossRef]

6. He, T.; Pausas, J.G.; Belcher, C.M.; Schwilk, D.W.; Lamont, B.B. Fire-adapted traits of pinus arose in the fiery cretaceous. New Phytol. 2012, 194, 751-759. [CrossRef] [PubMed]

7. He, T.; Belcher, C.M.; Lamont, B.B.; Lim, S.L. A 350-million-year legacy of fire adaptation among conifers. J. Ecol. 2016, 104, 352-363. [CrossRef]

8. Bell, D.T. Ecological response syndromes in the flora of southwestern Western Australia: Fire resprouters versus reseeders. Bot. Rev. 2001, 67, 417-440. [CrossRef]

9. Verdú, M. Ecological and evolutionary differences between Mediterranean seeders and resprouters. J. Veg. Sci. 2000, 11, 265-268. [CrossRef]

10. Keeley, J.E.; Fotheringham, C. Role of fire in regeneration from seed. In Seeds: The Ecology of Regeneration in Plant Communities; CABI Publishing: Wallingford, UK, 2000; pp. 311-330.

11. Bellingham, P.J.; Sparrow, A.D. Resprouting as a life history strategy in woody plant communities. Oikos 2000, 89, 409-416. [CrossRef]

12. Badik, K.J.; Jahner, J.P.; Wilson, J.S. A biogeographic perspective on the evolution of fire syndromes in pine trees (pinus: Pinaceae). R. Soc. Open Sci. 2018, 5, 172412. [CrossRef] [PubMed]

13. Schwilk, D.W.; Ackerly, D.D. Flammability and serotiny as strategies: Correlated evolution in pines. Oikos 2001, 94, 326-336. [CrossRef]

14. Bradshaw, S.D.; Dixon, K.W.; Hopper, S.D.; Lambers, H.; Turner, S.R. Response to Keeley et al.: Fire as an evolutionary pressure shaping plant traits. Trends Plant Sci. 2011, 16, 405. [CrossRef] [PubMed]

15. Keeley, J.E.; Pausas, J.G.; Rundel, P.W.; Bond, W.J.; Bradstock, R.A. Fire as an evolutionary pressure shaping plant traits. Trends Plant Sci. 2011, 16, 406-411. [CrossRef] [PubMed]

16. Mutch, R.W. Wildland fires and ecosystems-A hypothesis. Ecology 1970, 51, 1046-1051. [CrossRef] 
17. Rowe, J.S. Concepts of fire effects on plant individuals and species. In The Role of Fire in Northern Circumpolar Ecosystems: Scientific Committee on Problems of the Environment; Wein, R.W., MacLean, D.A., Eds.; John Wiley \& Sons Ltd.: Chichester, UK, 1983; pp. 135-180.

18. Schwilk, D.W. Dimensions of plant flammability. New Phytol. 2015, 206, 486-488. [CrossRef] [PubMed]

19. Pausas, J.G.; Keeley, J.E.; Schwilk, D.W. Flammability as an ecological and evolutionary driver. J. Ecol. 2017, 105, 289-297. [CrossRef]

20. Krawchuk, M.A.; Haire, S.L.; Coop, J.; Parisien, M.A.; Whitman, E.; Chong, G.; Miller, C. Topographic and fire weather controls of fire refugia in forested ecosystems of northwestern north America. Ecosphere 2016, 7, e01632. [CrossRef]

21. Archibald, S.; Lehmann, C.E.; Gómez-Dans, J.L.; Bradstock, R.A. Defining pyromes and global syndromes of fire regimes. Proc. Natl. Acad. Sci. USA 2013, 201211466. [CrossRef] [PubMed]

22. Archibald, S.; Lehmann, C.E.; Belcher, C.; Bond, W.J.; Bradstock, R.A.; Daniau, A.; Dexter, K.; Forrestel, E.; Greve, M.; He, T.; et al. Biological and geophysical feedbacks with fire in the earth system. Environ. Res. Lett. 2018, 13, 033003. [CrossRef]

23. Kasischke, E.S.; Turetsky, M.R. Recent changes in the fire regime across the North American boreal region-Spatial and temporal patterns of burning across Canada and Alaska. Geophys. Res. Lett. 2006, 33. [CrossRef]

24. Halofsky, J.; Donato, D.; Hibbs, D.; Campbell, J.; Cannon, M.D.; Fontaine, J.; Thompson, J.R.; Anthony, R.; Bormann, B.; Kayes, L.; et al. Mixed-severity fire regimes: Lessons and hypotheses from the Klamath-Siskiyou ecoregion. Ecosphere 2011, 2, 1-19. [CrossRef]

25. Kane, V.R.; Cansler, C.A.; Povak, N.A.; Kane, J.T.; McGaughey, R.J.; Lutz, J.A.; Churchill, D.J.; North, M.P. Mixed severity fire effects within the rim fire: Relative importance of local climate, fire weather, topography, and forest structure. For. Ecol. Manag. 2015, 358, 62-79. [CrossRef]

26. Keeley, J.E.; Zedler, P.H. Evolution of life histories in pinus. In Ecology and Biogeography of Pinus; Richardson, D.M., Ed.; Cambridge University Press: New York, NY, USA, 2000; pp. 219-251.

27. Barton, A.M. Intense wildfire in southeastern Arizona: Transformation of a Madrean oak-pine forest to oak woodland. For. Ecol. Manag. 2002, 165, 205-212. [CrossRef]

28. Barton, A.M. Pines versus oaks: Effects of fire on the composition of Madrean forests in Arizona. For. Ecol. Manag. 1999, 120, 143-156. [CrossRef]

29. Bennett, P.S.; Kunzmann, M.R. The applicability of generalized fire prescriptions to burning of madrean evergreen forest and woodland. J. Arizona-Nevada Acad. Sci. 1992, 24-25, 79-84.

30. Ffolliott, P.F.; Gottfried, G.J.; Bennett, D.A.; Ortega-Rubio, A.; Hamre, R. Tech. Coords. 1992. Ecology and Management of Oak and Associated Woodlands: Perspectives in the Southwestern United States and Northern Mexico; 1992 April 27-30; Sierra Vista, AZ; Gen. Tech. Rep. RM-GTR-218; U.S. Department of Agriculture, Forest Service, Rocky Mountain Forest and Range Experiment Station: Fort Collins, CO, USA, 1992; p. 224.

31. Preston, R.J. North American Trees; Iowa State College Press: Ames, IA, USA, 1948.

32. Barden, L.S. Serotiny and seed viability of pinus pungens in the southern Appalachians. Castanea 1979, 1, 44-47.

33. Mohr, H.H.; Waldrop, T.A.; Shelburne, V.B. Optimal Seedbed Requirements for Regenerating Table Mountain Pine; Gen. Tech. Rep. SRS-48; US Department of Agriculture, Forest Service, Southern Research Station: Asheville, NC, USA, 2002; pp. 306-309.

34. Williams, C.E. History and status of table mountain pine-pitch pine forests of the southern Appalachian Mountains (USA). Nat. Areas J. 1998, 18, 81-90.

35. Stone, E.; Stone, M. Root collar sprouts in pine. J. For. 1954, 52, 487-491.

36. McCune, B.; Mefford, M.J. PC-ORD. Multivariate Analysis of Ecological Data, version 6; MjM Software: Gleneden Beach, OR, USA, 2011.

37. Myers, N.; Mittermeier, R.A.; Mittermeier, C.G.; Da Fonseca, G.A.; Kent, J. Biodiversity hotspots for conservation priorites. Nature 2000, 403, 853-858. [CrossRef] [PubMed]

38. Rebelo, A. Saso Proteas: A Field Guide to the Proteas of Southern Africa; Fernwood Press in Association with the National Botanical Institute: Vlaeberg, South Africa, 2001; p. 240.

39. Thuiller, W.; Slingsby, J.A.; Privett, S.D.; Cowling, R.M. Stochastic species turnover and stable coexistence in a species-rich, fire-prone plant community. PLoS ONE 2007, 2, e938. [CrossRef] [PubMed] 
40. Lamont, B.B.; Le Maitre, D.; Cowling, R.; Enright, N. Canopy seed storage in woody plants. Bot. Rev. 1991, 57, 277-317. [CrossRef]

41. Tonnabel, J.; Schurr, F.M.; Boucher, F.; Thuiller, W.; Renaud, J.; Douzery, E.J.; Ronce, O. Life-history traits evolved jointly with climatic niche and disturbance regime in the genus leucadendron (proteaceae). Am. Nat. 2017, 191, 220-234. [CrossRef] [PubMed]

42. Pausas, J.G.; Keeley, J.E. Epicormic resprouting in fire-prone ecosystems. Trends Plant Sci. 2017, 22, 1008-1015. [CrossRef] [PubMed]

43. Climent, J.; Chambel, M.R.; López, R.; Mutke, S.; Alía, R.; Gil, L. Population divergence for heteroblasty in the canary island pine (Pinus canariensis, pinaceae). Am. J. Bot. 2006, 93, 840-848. [CrossRef] [PubMed]

44. Rodríguez-Trejo, D.A.; Fulé, P.Z. Fire ecology of Mexican pines and a fire management proposal. Int. J. Wildland Fire 2003, 12, 23-37. [CrossRef]

45. Viveros-Viveros, H.; Sáenz-Romero, C.; Vargas-Hernández, J.J.; López-Upton, J.; Ramírez-Valverde, G.; Santacruz-Varela, A. Altitudinal genetic variation in Pinus hartwegii Lindl. I: Height growth, shoot phenology, and frost damage in seedlings. For. Ecol. Manag. 2009, 257, 836-842. [CrossRef]

46. Lamant, T. Vegetative reproduction in gymnosperms. J. l'Association des Parcs Botaniques de France 2012, 53, 5.

47. Burns, R.M.; Barbara, H. Silvics of North America: 1. Conifers; 2. Hardwoods; Agriculture Handbook 654; U.S. Department of Agriculture, Forest Service: Washington, DC, USA, 1990; Volume 2, p. 877.

48. Ketcham, D.; Bethune, J. Fire resistance of south Florida slash pine. J. For. 1963, 61, 529-530.

49. Tapias, R.; Climent, J.; Pardos, J.A.; Gil, L. Life histories of Mediterranean pines. Plant Ecol. 2004, 171, 53-68. [CrossRef]

50. Ne'eman, G.; Goubitz, S.; Nathan, R. Reproductive traits of Pinus halepensis in the light of fire-A critical review. Plant Ecol. 2004, 171, 69-79. [CrossRef]

51. Daskalakou, E.N.; Thanos, C.A. Aleppo pine (Pinus halepensis) postfire regeneration: The role of canopy and soil seed banks. Int. J. Wildland Fire 1996, 6, 59-66. [CrossRef]

52. Koskela, J. Early shoot and diameter growth in four Pinus merkusii populations from Thailand. J. Trop. For. Sci. 2000, 12, 707-716.

53. Andersson, F. Coniferous Forests; Elsevier: San Diego, CA, USA, 2005; Volume 6.

54. Farjon, A. A Handbook of the World's Conifers (2 Vols.); Brill Academic Publisher: Boston, MA, USA, 2010.

55. Fernandes, P.M.; Rigolot, E. The fire ecology and management of maritime pine (Pinus pinaster ait.). For. Ecol. Manag. 2007, 241, 1-13. [CrossRef]

56. Gil, L.; López, R.; García-Mateos, Á.; González-Doncel, I. Seed provenance and fire-related reproductive traits of Pinus pinaster in central Spain. Int. J. Wildland Fire 2010, 18, 1003-1009. [CrossRef]

57. Little, S. Prescribed burning as a tool of forest management in the northeastern states. J. For. 1953, 51, 496-500.

58. Niering, W.A.; Dreyer, G.D. Effects of prescribed burning on andropogon scoparius in postagricultural grasslands in Connecticut. Am. Midl. Nat. 1989, 122, 88-102. [CrossRef]

59. Crutchfield, D.; Trew, I. Investigation of natural regeneration of pond pine. J. For. 1961, 59, 264-266.

60. Christensen, N.L. Shrubland fire regimes and their evolutionary consequences. In The Ecology of Natural Disturbance and Patch Dynamics; Pickett, S.T.A., White, P.S., Eds.; Academic Press: London, UK, 1985; pp. 85-100.

61. Wyse, S.V.; Perry, G.L.; O'Connell, D.M.; Holland, P.S.; Wright, M.J.; Hosted, C.L.; Whitelock, S.L.; Geary, I.J.; Maurin, K.J.; Curran, T.J. A quantitative assessment of shoot flammability for 60 tree and shrub species supports rankings based on expert opinion. Int. J. Wildland Fire 2016, 25, 466-477.

62. Bamber, R.; Mullette, K. Studies of the lignotubers of eucalyptus gummifera (gaertn. \& hochr.). Ii. Anatomy. Aust. J. Bot. 1978, 26, 15-22.

63. Carrodus, B.; Blake, T. Studies on the lignotubers of eucalyptus obliqua l'heri. I. The nature of the lignotuber. New Phytol. 1970, 69, 1069-1072. [CrossRef]

64. Crisp, M.D.; Burrows, G.E.; Cook, L.G.; Thornhill, A.H.; Bowman, D.M. Flammable biomes dominated by eucalypts originated at the cretaceous-palaeogene boundary. Nat. Commun. 2011, 2, 193. [CrossRef] [PubMed]

65. Nichols, J.D.; Bristow, M.; Vanclay, J.K. Mixed-species plantations: Prospects and challenges. For. Ecol. Manag. 2006, 233, 383-390. [CrossRef] 
66. Lacey, C.J. Rhizomes in tropical eucalypts and their role in recovery from fire damage. Aust J. Bot. 1974, 22, 29-38. [CrossRef]

67. Nicolle, D. A classification and census of regenerative strategies in the eucalypts (angophora, corymbia and eucalyptus-Myrtaceae), with special reference to the obligate seeders. Aust. J. Bot. 2006, 54, 391-407. [CrossRef]

68. Lacey, C.; Whelan, P. Observations on the ecological significance of vegetative reproduction in the katherine-darwin region of the northern territory. Aust. For. 1976, 39, 131-139. [CrossRef]

69. Murphy, B.P.; Bradstock, R.A.; Boer, M.M.; Carter, J.; Cary, G.J.; Cochrane, M.A.; Fensham, R.J.; Russell-Smith, J.; Williamson, G.J.; Bowman, D.M. Fire regimes of Australia: A pyrogeographic model system. J. Biogeogr. 2013, 40, 1048-1058. [CrossRef]

70. Tng, D.; Williamson, G.; Jordan, G.; Bowman, D. Giant eucalypts-Globally unique fire-adapted rain-forest trees? New Phytol. 2012, 196, 1001-1014. [CrossRef] [PubMed]

71. Turner, P.A.; Balmer, J.; Kirkpatrick, J. Stand-replacing wildfires? The incidence of multi-cohort and single-cohort eucalyptus regnans and e. Obliqua forests in southern Tasmania. For. Ecol. Manag. 2009, 258, 366-375. [CrossRef]

72. Bowman, D.M.; Williamson, G.J.; Prior, L.D.; Murphy, B.P. The relative importance of intrinsic and extrinsic factors in the decline of obligate seeder forests. Glob. Ecol. Biogeogr. 2016, 25, 1166-1172. [CrossRef]

73. Lindenmayer, D.; Cunningham, R.; Donnelly, C.; Franklin, J. Structural features of old-growth Australian montane ash forests. For. Ecol. Manag. 2000, 134, 189-204. [CrossRef]

74. Gosper, C.R.; Prober, S.M.; Yates, C.J. Continental-scale syntheses of Australian pyromes-misclassification of south-western eucalypt woodlands misinforms management. J. Biogeogr. 2016, 43, 858-861. [CrossRef]

75. Moore, G.M. The role of lignotubers (basal burls) in the stress recovery of messmate stringybark, eucalyptus obliqua l'herit. Seedlings and its arboricultural implications. Arboricult. J. 2015, 37, 113-125. [CrossRef]

76. Dutkowski, G.W.; Potts, B.M. Geographic patterns of genetic variation in eucalyptus globulus ssp. Globulus and a revised racial classification. Aust. J. Bot. 1999, 47, 237-263.

77. Ladiges, P.Y.; Ashton, D. Variation in some Central Victoria populations of eucalyptus viminalis labill. Aust. J. Bot. 1974, 22, 81-102. [CrossRef]

78. Shugart Jr, H.; Noble, I. A computer model of succession and fire response of the high-altitude eucalyptus forest of the brindabella range, Australian Capital Territory. Aust. J. Bot. 1981, 6, 149-164. [CrossRef]

79. Bowman, D.M.; Murphy, B.P.; Neyland, D.L.; Williamson, G.J.; Prior, L.D. Abrupt fire regime change may cause landscape-wide loss of mature obligate seeder forests. Glob. Chang. Biol. 2014, 20, 1008-1015. [CrossRef] [PubMed]

80. Bassett, O.D.; Prior, L.D.; Slijkerman, C.M.; Jamieson, D.; Bowman, D.M. Aerial sowing stopped the loss of alpine ash (eucalyptus delegatensis) forests burnt by three short-interval fires in the alpine national park, Victoria, Australia. For. Ecol. Manag. 2015, 342, 39-48. [CrossRef]

81. Doherty, M.D.; Gill, A.M.; Cary, G.J.; Austin, M.P. Seed viability of early maturing alpine ash (eucalyptus delegatensis subsp. Delegatensis) in the Australian Alps, south-eastern Australia, and its implications for management under changing fire regimes. Aust. J. Bot. 2017, 65, 517-523. [CrossRef]

82. Bowman, D.; Kirkpatrick, J. Establishment, suppression and growth of eucalyptus delegatensis r.T. Baker in multiaged forests. I. The effects of fire on mortality and seedling establishment. Aust. J. Bot. 1986, 34, 63-72. [CrossRef]

83. Ellis, R. The relationships among eucalypt forest, grassland and rainforest in a highland area in north-eastern Tasmania. Aust. J. Ecol. 1985, 10, 297-314. [CrossRef]

84. Kolden, C.A.; Bleeker, T.; Smith, A.; Poulos, H.M.; Camp, A.E. Fire effects on historical wildfire refugia in contemporary wildfires. Forests 2017, 8, 400. [CrossRef]

85. Enright, N.; Keith, D.A.; Clarke, M.F.; Miller, B.P. Fire regimes in Australian sclerophyllous shrubby ecosystems: Heathlands, heathy woodlands. In Flammable Australia: Fire Regimes and Biodiversity in a Changing World; CSIRO Publishing: Collingwood, Australia, 2012; pp. 215-235.

86. Gonzalez, M.E.; Veblen, T.T.; Sibold, J.S. Influence of fire severity on stand development of araucaria araucana-Nothofagus pumilio stands in the Andean cordillera of south-central Chile. Aust. Ecol. 2010, 35, 597-615. [CrossRef]

87. Fulé, P.Z.; Crouse, J.E.; Heinlein, T.A.; Moore, M.M.; Covington, W.W.; Verkamp, G. Mixed-severity fire regime in a high-elevation forest of Grand Canyon, Arizona, USA. Landsc. Ecol. 2003, 18, 465-486. [CrossRef] 
88. Cohn, J.S.; Di Stefano, J.; Christie, F.; Cheers, G.; York, A. How do heterogeneity in vegetation types and post-fire age-classes contribute to plant diversity at the landscape scale? For. Ecol. Manag. 2015, 346, 22-30. [CrossRef]

89. Parr, C.L.; Andersen, A.N. Patch mosaic burning for biodiversity conservation: A critique of the pyrodiversity paradigm. Conserv. Biol. 2006, 20, 1610-1619. [CrossRef] [PubMed]

90. Clarke, P.J.; Lawes, M.J.; Murphy, B.P.; Russell-Smith, J.; Nano, C.E.M.; Bradstock, R.; Enright, N.J.; Fontaine, J.B.; Gosper, C.R.; Radford, I.; et al. A synthesis of postfire recovery traits of woody plants in australian ecosystems. Sci. Total Environ. 2015, 534, 31-42. [CrossRef] [PubMed]

91. He, T.; Lamont, B.B. Baptism by fire: The pivotal role of ancient conflagrations in evolution of the earth's flora. Nat. Sci. Rev. 2017, 5, 237-254. [CrossRef]

92. Lamont, B.B.; Enright, N.J.; He, T. Fitness and evolution of resprouters in relation to fire. Plant Ecol. 2011, 212, 1945-1957. [CrossRef]

93. Perry, D.A.; Hessburg, P.F.; Skinner, C.N.; Spies, T.A.; Stephens, S.L.; Taylor, A.H.; Franklin, J.F.; McComb, B.; Riegel, G. The ecology of mixed severity fire regimes in Washington, Oregon, and northern California. For. Ecol. Manag. 2011, 262, 703-717. [CrossRef]

94. Baker, W.L. Transitioning western us dry forests to limited committed warming with bet-hedging and natural disturbances. Ecosphere 2018, 9, e02288. [CrossRef]

95. Barga, S.; Dilts, T.E.; Leger, E.A. Climate variability affects the germination strategies exhibited by arid land plants. Oecologia 2017, 185, 437-452. [CrossRef] [PubMed]

96. He, T.; Lamont, B.B.; Enright, N.J.; D’Agui, H.M.; Stock, W. Environmental drivers and genomic architecture of trait differentiation in fire-adapted banksia attenuata ecotypes. J. Integr. Plant Biol. 2018. [CrossRef] [PubMed]

97. Radeloff, V.C.; Mladenoff, D.J.; Guries, R.P.; Boyce, M.S. Spatial patterns of cone serotiny in pinus banksiana in relation to fire disturbance. For. Ecol. Manag. 2004, 189, 133-141. [CrossRef]

98. Muir, P.S.; Lotan, J.E. Disturbance history and serotiny of pinus contorta in western Montana. Ecology 1985, 66, 1658-1668. [CrossRef]

99. Givnish, T.J. Serotiny, geography, and fire in the pine barrens of New Jersey. Evolution 1981, 35, 101-123. [CrossRef] [PubMed]

100. Ledig, F.T.; Fryer, J.H. A pocket of variability in pinus rigida. Evolution 1972, 26, 259-266. [CrossRef] [PubMed] 